\begin{tabular}{r|l|l|l}
$\begin{array}{c}\text { Case Reports in } \\
\text { Gastroenterology }\end{array}$ & $\begin{array}{l}\text { Case Rep Gastroenterol 2010;4:356-360 } \\
\text { DOl: 10.1159/000320687 }\end{array}$ & $\begin{array}{l}\text { Published online: } \\
\text { September 15, 2010 }\end{array}$ & $\begin{array}{l}\text { O 2010 S. Karger AG, Basel } \\
\text { ISSN 1662-0631 } \\
\text { www.karger.com/crg }\end{array}$ \\
\hline
\end{tabular}

This is an Open Access article licensed under the terms of the Creative Commons AttributionNonCommercial-NoDerivs 3.0 License (www.karger.com/OA-license), applicable to the online version of the article only. Distribution for non-commercial purposes only.

\title{
Spontaneous Cholecystocutaneous Fistula
}

\author{
Raffaele Pezzillia ${ }^{\mathrm{a}}$ Bahjat Barakat ${ }^{\mathrm{b}}$ Roberto Corinaldesi ${ }^{\mathrm{a}}$ \\ Mario Cavazza ${ }^{b}$ \\ ${ }^{\mathrm{a}}$ Department of Digestive Diseases and Internal Medicine and ${ }^{\mathrm{b}}$ Emergency \\ Department, Sant'Orsola-Malpighi Hospital, Bologna, Italy
}

\section{Key Words}

Drainage · Fistula · Gallstones

\begin{abstract}
Spontaneous cholecystocutaneous fistula is a rare complication of chronic calculous cholecystitis because currently gallstones are diagnosed and treated at an early stage. This occurrence is possible even if it seems actually to be rare. We report the case of a 90-year-old woman admitted to our hospital with diarrhea of 4 days duration and low-grade fever $\left(37.5^{\circ} \mathrm{C}\right)$. On physical examination, she had a $10 \times 10 \mathrm{~cm}$ erythematous swelling and discomfort of the upper right abdominal quadrant; the skin and mucosae were dry. Transabdominal ultrasonography showed a gallbladder with abnormalities of the wall, a single gallstone impacted in the infundibulum and a fluid collection with irregular margins containing fluctuating echoes adjacent to the anterior abdominal wall of the upper right abdominal quadrant. A diagnosis of spontaneous cholecystocutaneous fistula with an abdominal purulent collection was reached. Due to the high anesthesiological risk of the patient, conservative management was carried out with fluids, broad-spectrum antibiotic, albumin and calcium supplementation. Computed tomography drainage of the purulent collection was also carried out. Both clinical and laboratory parameters substantially improved during the following two days, but on the third day of hospitalization, the patient died from a sudden arrhythmic event.
\end{abstract}

\section{Introduction}

Spontaneous cholecystocutaneous fistula is a rare complication of chronic calculous cholecystitis because currently gallstones are diagnosed and treated at an early stage. This complication is possible even if it seems actually to be rare. 


\begin{tabular}{r|l|l|l}
$\begin{array}{r}\text { Case Reports in } \\
\text { Gastruanteriology }\end{array}$ & $\begin{array}{l}\text { Case Rep Gastroenterol 2010;4:356-360 } \\
\text { DOI: 10.1159/000320687 }\end{array}$ & $\begin{array}{l}\text { Published online: } \\
\text { September 15, 2010 }\end{array}$ & $\begin{array}{l}\text { O 2010 S. Karger AG, Basel } \\
\text { ISSN 1662-0631 } \\
\text { www.karger.com/crg }\end{array}$ \\
\hline
\end{tabular}

\section{Case Report}

A 90-year-old woman was admitted to the hospital with diarrhea of 4 days duration (5-6 small bowel movements per day) and low-grade fever $\left(37.5^{\circ} \mathrm{C}\right)$. She had a history of COPD, ischemic heart disease, ischemic stroke with stabilized neurological deficit (tetraparesis, aphasia, swallowing difficulties) and psychosis associated with schizophrenia. She was on parenteral nutrition using a central venous access device (Port-A-Cath ${ }^{\circledR}$ device, Smiths Medical, Ashford, Kent, UK) and she was being chronically treated with angiotensin-converting enzyme inhibitors, furosemide and a neuroleptically active isomer of clopenthixol.

On physical examination, she had a $10 \times 10 \mathrm{~cm}$ erythematous swelling and discomfort of the upper right abdominal quadrant; the skin and mucosae were dry. Arterial pressure was $100 / 60 \mathrm{~mm} \mathrm{Hg}$, heart rate was $100 \mathrm{bpm}$ and $\mathrm{O}_{2}$ saturation in ambient air was 95\%. Laboratory investigation revealed:

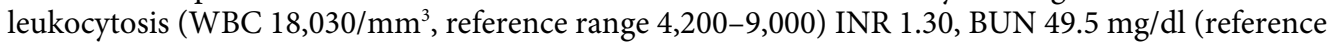
range 7.0-23), serum creatinine $1.89 \mathrm{mg} / \mathrm{dl}$ (reference range $0.50-1.20$ ), serum albumin $2.1 \mathrm{~g} / \mathrm{dl}$ and serum calcium $7.0 \mathrm{mg} / \mathrm{dl}$ (reference range 8.5-10.5). Total bilirubin, serum concentrations of AST, ALT and $\mathrm{LDH}$, amylase and lipase were within the normal reference limits. Transabdominal ultrasonography (fig. 1) showed a gallbladder with abnormalities of the wall, a single gallstone $2.8 \mathrm{~cm}$ in diameter impacted in the infundibulum and a fluid collection of $6 \times 7 \mathrm{~cm}$ with irregular margins containing fluctuating echoes adjacent to the anterior abdominal wall of the upper right abdominal quadrant. Abdominal computed tomography (CT) was performed; it confirmed the ultrasonographic finding and also showed notable communication between the gallbladder and the subcutaneous abdominal collection (fig. 2).

A diagnosis of spontaneous cholecystocutaneous fistula with an abdominal purulent collection was reached. Due to the high anesthesiological risk of the patient, a conservative management was carried out with fluids, broad-spectrum antibiotic, albumin and calcium supplementation. CT drainage of the purulent collection was also carried out (fig. 3 , fig. 4). Both clinical and laboratory parameters substantially improved during the following two days, but on the third day of hospitalization, the patient died from a sudden arrhythmic event.

\section{Discussion}

Spontaneous cholecystocutaneous fistula was a common complication of gallstones until the beginning of the twentieth century and a total of 226 cases have been reported until now [1]. At present, spontaneous cholecystocutaneous fistula is a rare complication of chronic calculous cholecystitis because currently gallstones are diagnosed and treated at an early stage [1]. Most patients are females over 50 years of age, and an erythematous skin lesion may be the only presenting sign. It has been suggested that associated diseases (polyarterites nodosa, typhoid, bacterial dissemination, and trauma) or drug treatments, such as steroids, may be predisposing factors [1]. External fistulas have been reported as a result of the chronic perforation of the gallbladder, and obstruction of the cystic duct by a stone plays an important role in the pathophysiology of perforation; adherence to the abdominal wall and necrosis of the gallbladder lead to fistula formation [2]. The clinical presentation of a cutaneous biliary fistula is variable and depends on the anatomical course; an external fistula drains more frequently in the right superior abdominal quadrant, right flank or umbilicus, even if the opening fistula tract may be present in the left-side costal margin, right-side iliac fossa, right groin or right gluteus [1]. Ultrasonography and CT are presently the best imaging modalities for diagnosing this complication, and laparoscopic cholecystectomy has been suggested as a definitive treatment modality. However, percutaneous treatment can be considered in high-risk patients [3]. 


\begin{tabular}{r|l|l|l}
$\begin{array}{r}\text { Case Reports in } \\
\text { Gastruanteriology }\end{array}$ & $\begin{array}{l}\text { Case Rep Gastroenterol 2010;4:356-360 } \\
\text { DOI: 10.1159/000320687 }\end{array}$ & $\begin{array}{l}\text { Published online: } \\
\text { September 15, 2010 }\end{array}$ & $\begin{array}{l}\text { O 2010 S. Karger AG, Basel } \\
\text { ISSN 1662-0631 } \\
\text { www.karger.com/crg }\end{array}$ \\
\hline
\end{tabular}

\section{Disclosure Statement}

The authors have no conflict of interest to declare.
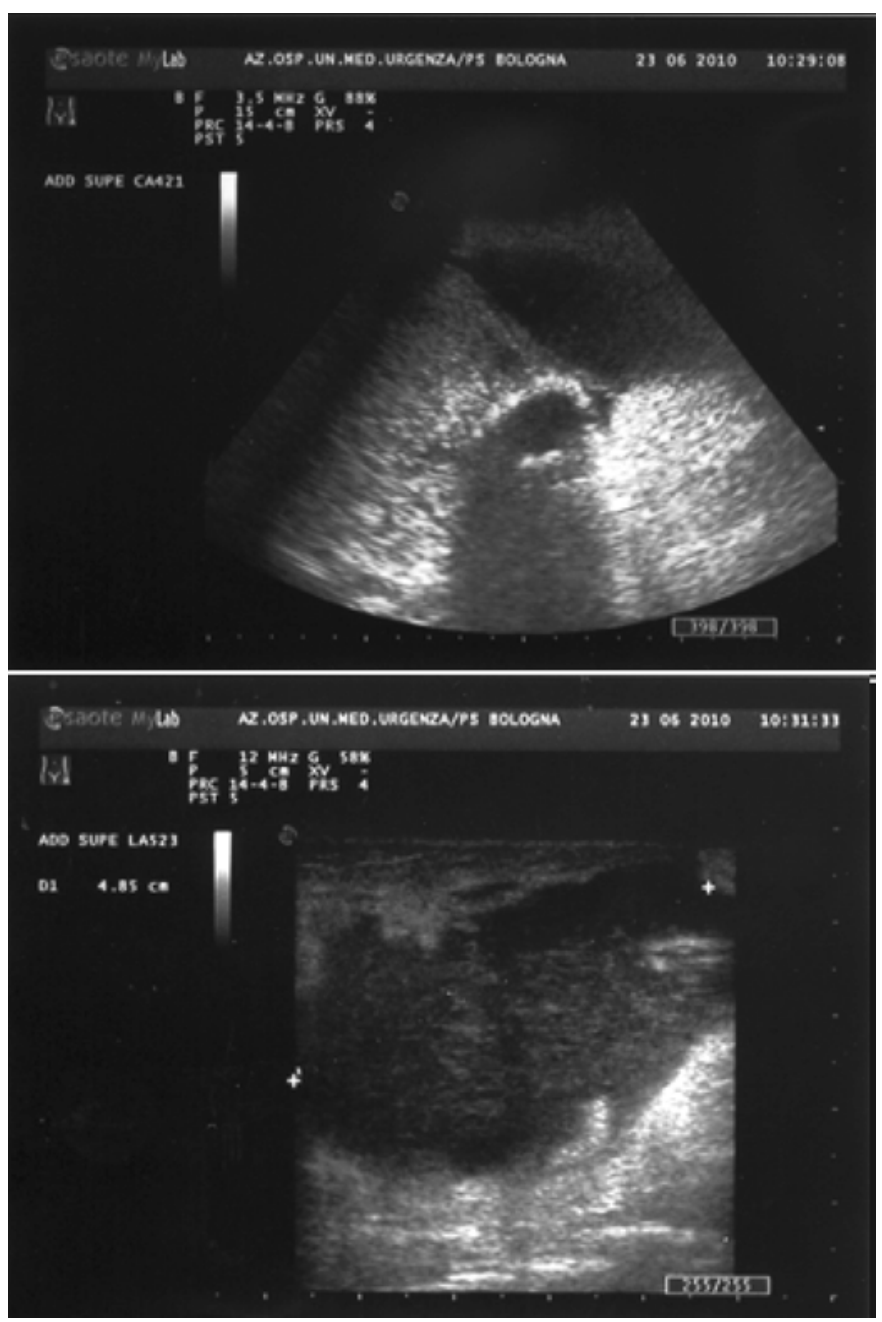

Fig. 1. Transabdominal ultrasonography. Upper quadrant: gallbladder with abnormalities of the wall, a single gallstone of $2.8 \mathrm{~cm}$ of diameter impacted in the infundibulum. Lower quadrant: fluid collection of $6 \times 7 \mathrm{~cm}$ with irregular margins containing fluctuating echoes adjacent to the anterior abdominal wall of the upper right abdominal quadrant. 


\begin{tabular}{r|l|l|l}
$\begin{array}{r}\text { Case Reports in } \\
\text { Gastroenterology }\end{array}$ & $\begin{array}{l}\text { Case Rep Gastroenterol 2010;4:356-360 } \\
\text { DOl: 10.1159/000320687 }\end{array}$ & $\begin{array}{l}\text { Published online: } \\
\text { September 15, 2010 }\end{array}$ & $\begin{array}{l}\text { O 2010 S. Karger AG, Basel } \\
\text { ISSN 162--0631 } \\
\text { www.karger.com/crg }\end{array}$ \\
\hline
\end{tabular}

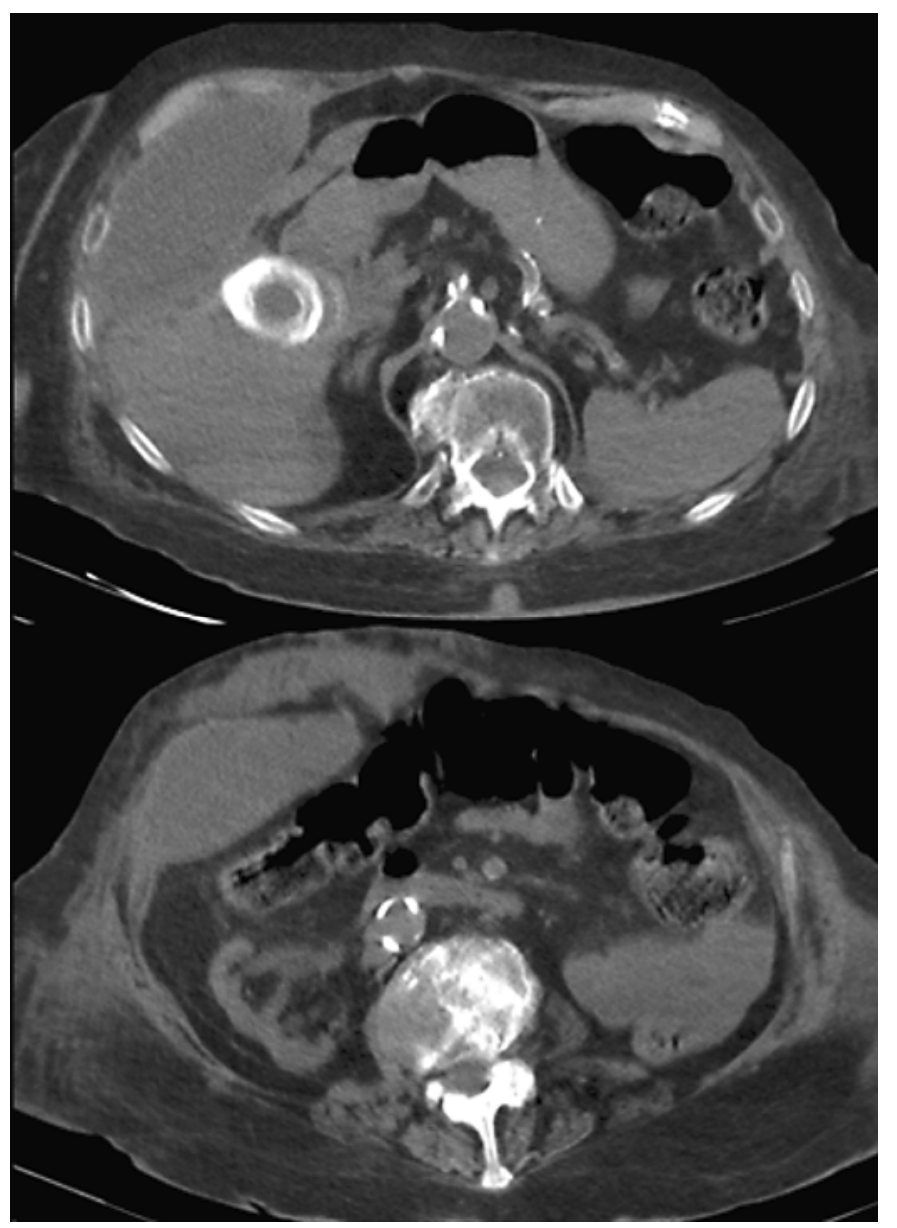

Fig. 2. CT. Upper quadrant: gallbladder with a single gallstone $2.8 \mathrm{~cm}$ in diameter impacted in the infundibulum. Lower quadrant: fluid collection of $6 \times 7 \mathrm{~cm}$ adjacent to the anterior abdominal wall of the upper right abdominal quadrant.

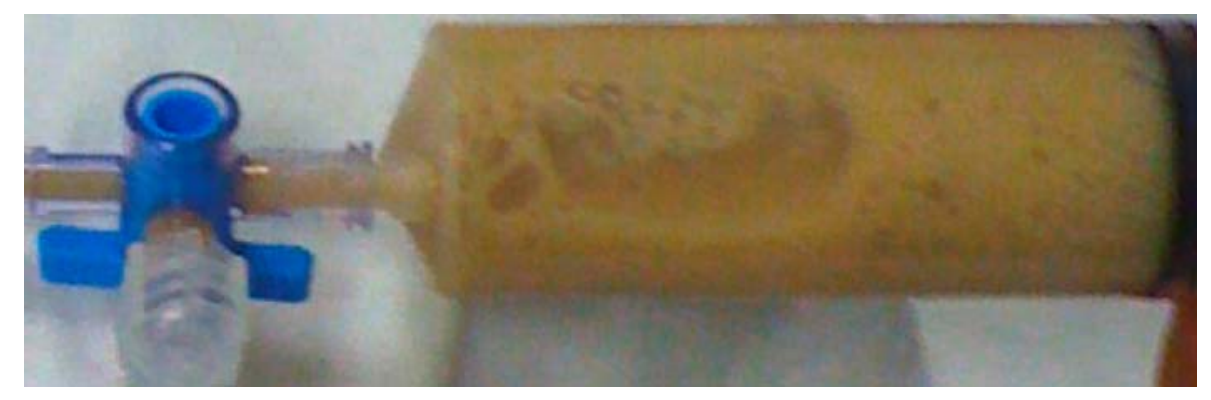

Fig. 3. Purulent appearance of the abdominal collection. 


\begin{tabular}{r|l|l|l} 
Case Reports in & $\begin{array}{l}\text { Case Rep Gastroenterol 2010;4:356-360 } \\
\text { DOI: 10.1159/000320687 }\end{array}$ & $\begin{array}{l}\text { Published online: } \\
\text { September 15, 2010 }\end{array}$ & $\begin{array}{l}\odot \text { 2010 S. Karger AG, Basel } \\
\text { ISSN 1662-0631 } \\
\text { www.karger.com/crg }\end{array}$ \\
\hline
\end{tabular}

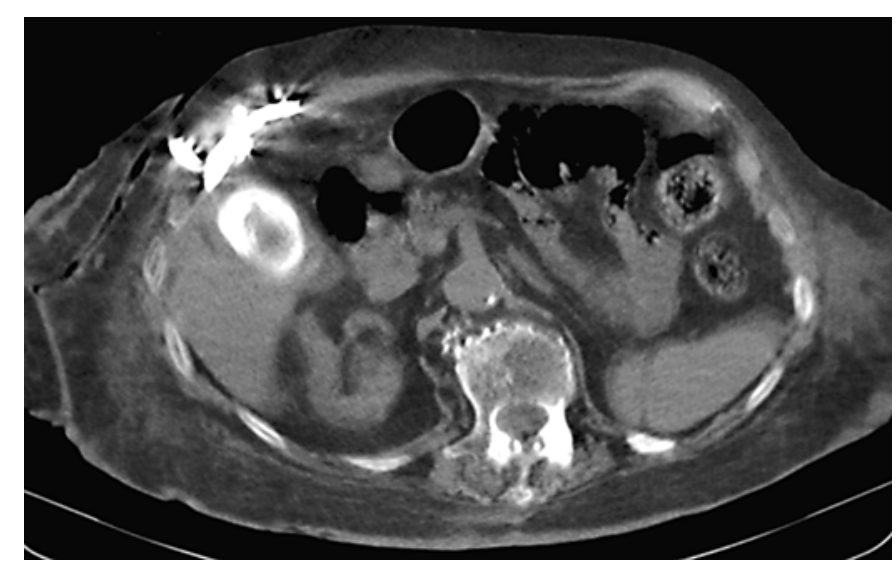

Fig. 4. CT drainage of the abdominal fluid collection.

\section{References}

1 Yüceyar S, Ertürk S, Karabiçak I, Onur E, Aydoğan F: Spontaneous cholecystocutaneous fistula presenting with an abscess containing multiple gallstones: a case report. Mt Sinai J Med 2005;72:402-404.

2 Urban CA, Urban LABD, Lima RS, Bleggi-Torres LF: Spontaneous combined internal and external biliary fistulae in association with gallstones and gliomatosis of the gallbladder. Rev Bras Cancerologia 2001;47:273276.

-3 Davies MG, Tadros E, Gaine S, McEntee GP, Gorey TF, Hennessy TP: Combined internal and external biliary fistulae treated by percutaneous cholecystlithotomy. Br J Surg 1989;76:1258.

All authors participated in the acquisition, analysis and interpretation of data; Raffaele Pezzilli wrote the manuscript. All authors approved the final version of the manuscript. 